\title{
Restoration of antibiotic susceptibility in fluoroquinolone-resistant Escherichia coli by targeting acrB with antisense phosphorothioate oligonucleotide encapsulated in novel anion liposome
}

\author{
Jingru Meng ${ }^{1,3}$, Hui Bai ${ }^{2,3}$, Min Jia ${ }^{1}$, Xue Ma ${ }^{1}$, Zheng Hou ${ }^{1}$, Xiaoyan Xue ${ }^{1}$, Ying Zhou ${ }^{1}$ and Xiaoxing Luo ${ }^{1}$ \\ Fluoroquinolone-resistant Escherichia coli (FREC) is one of the leading causes of Gram-negative bacterial infections short of \\ effective antibiotics, thus necessitating development of novel antibacterial agents such as antisense resistance inhibitors. \\ Aiming to restore susceptibility of FREC to fluoroquinolones by antisense inhibition of essential resistance mechanism, we \\ designed and synthesized anion liposome encapsulated phosphorothioate oligodeoxynucleotide 831 (PS-ODN831) targeting gene \\ acrB, which encodes the AcrAB-TolC efflux pump responsible for decreasing intercellular antibiotic concentrations. In all \\ encapsulated PS-ODN831-treated groups, the MICs of ciprofloxacin and levofloxacin to FREC were reduced at different degrees, \\ therefore inhibiting growth of FREC in a concentration-dependent manner. Reversion of their bactericidal effects was the result \\ of specific and potent inhibition of acrB mRNA and the activity of efflux pump of AcrAB-TolC in FREC strains by liposome- \\ encapsulated PS-ODN831. The study indicated that antisense targeting of AcrAB-TolC efflux pump system may be a feasible \\ and potential strategy to treat FREC infections.
}

The Journal of Antibiotics (2012) 65, 129-134; doi:10.1038/ja.2011.125; published online 21 December 2011

Keywords: $a c r B$; anionic liposome; antisense antibacterial strategy; efflux pump; fluoroquinolone-resistant Escherichia coli (FREC); phosphorothioate oligodeoxynucleotide (PS-ODN)

\section{INTRODUCTION}

Escherichia coli is the most common etiologic agent of Gram-negative bacilli and often causes extraintestinal infections in its hosts. ${ }^{1}$ Infections caused by E. coli are routinely treated with quinolones and fluoroquinolones, which belong to the most-frequently prescribed antibiotic classes.,3 Quinolones and fluoroquinolones, with their enhanced systemic activity against many Gram-negative bacteria, have been widely used since the first introduction of ciprofloxacin in $1987 .{ }^{4}$ Unfortunately, as the use of fluoroquinolones increases, fluoroquinolone therapies are also threatened by an increasing prevalence of fluoroquinolone-resistant E. coli (FREC). ${ }^{5,6}$ In Beijing, from 1997 to 1999, approximately $60 \%$ of E. coli strains isolated from hospital-acquired infections and $50 \%$ of those isolated from the community were resistant to ciprofloxacin. ${ }^{7}$ In Japan, the isolation frequency of levofloxacin-resistant clinical isolates of $E$. coli increased from 14.6 to $20.8 \%$ from 2003 to $2008 .^{8}$ According to the European resistance surveillance network, a significant increase of fluoroquinolone resistance was observed for E. coli between 2002 and 2009, and the majority of countries reported resistant proportions to be $>20 \%$, reaching up to $43.4 \%$. Although the number of FREC strains is increasing all over the world, no new antibiotics are under development to provide plausible therapeutic choices. ${ }^{9}$ Thus, it is urgently needed that novel alternative strategies with mechanisms radically different from the existing ones can be used to combat FREC.

The concept of using the antisense approach to combat antibioticresistant bacteria is revolutionary. Antisense oligomers target specific genes and inhibit transcription and expression of the targeted sequence. Sequence data of the entire genome of pathogenic bacteria or of multiple isolates of a single pathogen have provided new insights into the microevolution of a species as well as newly generated targets for antimicrobials. ${ }^{10}$ Base sequence-specific antisense antibiotics are now more attractive than ever. They can be rapidly synthesized, targeting any gene with known sequence and being structurally modified to overcome any resistance that may arise. ${ }^{11}$ Our previous results have demonstrated that the blockage of resistant gene expression of methicillin-resistant Staphylococcus aureus and multidrug-resistant Pseudomonas aeruginosa by phosphorothioate oligodeoxynucleotide (PS-ODN) or deoxyribozyme leads to significant reduction of resistant gene mRNAs. As a result, the susceptibility of methicillin-resistant $S$. aureus and multidrug-resistant $P$. aeruginosa

${ }^{1}$ Department of Pharmacology, School of Pharmacy, Fourth Military Medical University, Xi'an, China and ${ }^{2}$ Beijing Institute of Radiation Medicine, Beijing, PR China Correspondence: Professor X Luo, Department of Pharmacology, School of Pharmacy, Fourth Military Medical University, No.17 Changle West Rd., Xi'an 710032 , Shaanxi, China. E-mail: xxluo3@fmmu.edu.cn

${ }^{3}$ These authors contributed equally to this work.

Received 13 September 2011; revised 24 November 2011; accepted 27 November 2011; published online 21 December 2011 
to some antibiotics has been restored to a significant level. ${ }^{12-16}$ Fluoroquinolone resistant clinical strains of $E$. coli frequently show an upregulated AcrAB-TolC system in addition to alterations in targets DNA gyrase and Topoisomerase IV, which suggests that the pump may provide some advantages in the clinical setting.

In the current study, we used the specific anti-acr $B$ antisense PS-ODN for inhibiting the expression of acrB mRNA, thereby restoring the susceptibility of $E$. coli to fluoroquinolones.

\section{RESULTS}

Reversal of antibiotic resistance of FREC 070701 by encapsulated anti-acrB PS-ODN831

We found that the number of FREC070701 colonies on the MuellerHinton agar containing ciprofloxacin $\left(6 \mu \mathrm{g} \mathrm{ml}^{-1}\right)$ or levofloxacin $\left(12 \mu \mathrm{g} \mathrm{ml}^{-1}\right)$ decreased significantly in all envelopment anti-acrB PS-ODN831 liposome-treated groups in a concentration-dependent manner. When FREC070701 strain was treated with liposome-encapsulated $100 \mu \mathrm{g} \mathrm{ml}^{-1}$ anti-acrB PS-ODN831, the number of colonies in Mueller-Hinton agar containing $6 \mu \mathrm{g} \mathrm{ml}^{-1}$ of ciprofloxacin decreased from $5.15 \times 10^{9}$ to $1.2 \times 10^{8}$ cells ml $^{-1}$ and the number of colonies in Mueller-Hinton agar containing $12 \mu \mathrm{g} \mathrm{ml}^{-1}$ of levofloxacin decreased from $3.88 \times 10^{9}$ to $1.42 \times 10^{8}$ cells $\mathrm{ml}^{-1}$. The number of FREC070701 colonies on the Mueller-Hinton agar containing ciprofloxacin $\left(6 \mu \mathrm{g} \mathrm{ml}^{-1}\right)$ decreased to $33.4,9.9,6.6$ and $2.3 \%$ of the control value in all encapsulated PS-ODN831-treated groups at 3, 10, 30 and $100 \mu \mathrm{g} \mathrm{ml}^{-1}$, respectively (Figure 1a). Similarly, we also observed that compared with the control group, the number of FREC070701 colonies from all anti-acrB liposome-encapsulated PS-ODN831 at 3, 10,30 and $100 \mu \mathrm{g} \mathrm{m}^{-1}$ on the Mueller-Hinton agar containing levofloxacin $\left(12 \mu \mathrm{g} \mathrm{ml}^{-1}\right)$ significantly decreased to $34.8,21.2,7.0$ and $3.7 \%$, respectively, of the control value (Figure $1 \mathrm{~b}$ ). However, the growth of FREC070701 was not influenced in the liposomeencapsulated PBS, liposome-encapsulated mismatched PS-ODN0701 $\left(100 \mu \mathrm{g} \mathrm{ml}^{-1}\right)$, free PEI-treated group $\left(5.5 \mu \mathrm{g} \mathrm{ml}^{-1}\right)$, but was only slightly inhibited in the free PS-ODN831-treated group $\left(100 \mu \mathrm{g} \mathrm{ml}^{-1}\right)$, which indicated that a small amount of free PSODN831 could enter into the bacteria through the cell wall of bacteria (Figures $1 \mathrm{a}$ and $\mathrm{b}$ ).

Additional experiments were performed to determine growth rate of FREC070701 in ciprofloxacin $\left(6 \mu \mathrm{g} \mathrm{ml}^{-1}\right)$ or levofloxacin $\left(12 \mu \mathrm{g} \mathrm{ml}^{-1}\right)$ containing liquid medium (Figure 2). The results showed that the growth of FREC070701 was appreciably inhibited when it was treated with different concentrations of encapsulated anti-acrB PS-ODN831 liposome concentration-dependently as compared with cells grown in control group (Figures $2 \mathrm{~b}$ and $\mathrm{d}$ ). However, the growth of FREC070701 in ciprofloxacin $\left(6 \mu \mathrm{g} \mathrm{ml}^{-1}\right)$ or levofloxacin $\left(12 \mu \mathrm{g} \mathrm{ml}^{-1}\right)$ containing liquid medium was not influenced by the treatment with liposome-encapsulated PBS, liposome-encapsulated mismatched PS-ODN0701 $\left(100 \mu \mathrm{g} \mathrm{ml}^{-1}\right)$, free PEI $\left(5.5 \mu \mathrm{g} \mathrm{ml}^{-1}\right)$ and free PS-ODN831 $\left(100 \mu \mathrm{g} \mathrm{ml}^{-1}\right)$ (Figures $2 \mathrm{a}$ and c).

Restoration of antibiotic susceptibility of FREC070701 to clinical commonly used antibiotics ciprofloxacin and levofloxacin

Furthermore, we observed the change of MIC of ciprofloxacin and levofloxacin against FREC070701 in the presence or absence of encapsulated anti-acrB PS-ODN831 liposome. FREC070701 showed the strong resistance to ciprofloxacin and levofloxacin. The MICs of ciprofloxacin and levofloxacin were 64 and $32 \mu \mathrm{g} \mathrm{ml}^{-1}$, respectively. The MICs of ciprofloxacin to FREC070701 were reduced at different degrees in the presence of liposome-encapsulated PS-ODN831 at 3, 10,30 and $100 \mu \mathrm{g} \mathrm{ml}^{-1}$. After treatment with $100 \mu \mathrm{g} \mathrm{ml}{ }^{-1}$ liposome-
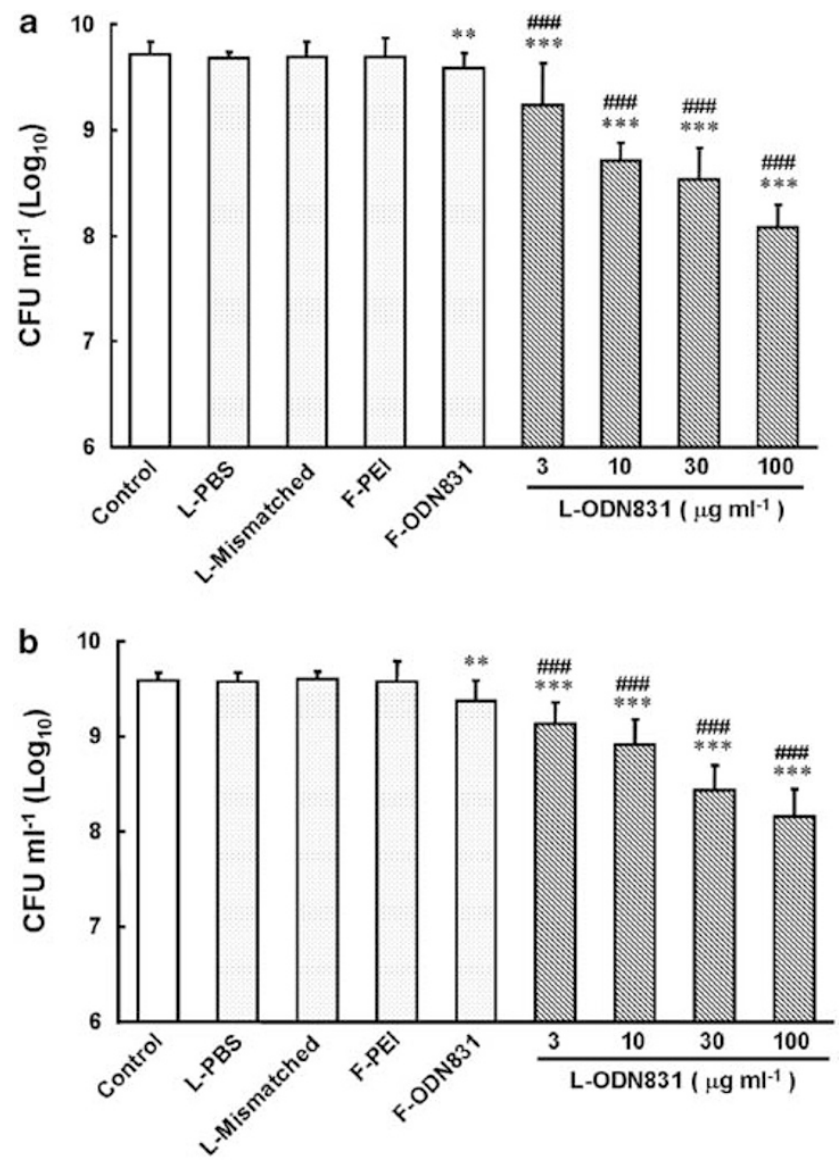

Figure 1 Effects of anti-acrB encapsulated PS-ODN831 on the growth of FREC070701 colonies. (a) Colony forming unit (CFU) of FREC070701 on Mueller-Hinton agar containing $6 \mu \mathrm{gl}^{-1}$ of ciprofloxacin. (b) CFU of FREC070701 on Mueller-Hinton agar containing $12 \mu \mathrm{g} \mathrm{m} l^{-1}$ of levofloxacin. The data were shown as mean \pm s.d. of 10 samples, ${ }^{* * P} P<0.05$ vs control, $* * * P<0.01$ vs control, $\# \# \#<0.01$ vs free PS-ODN831.

encapsulated PS-ODN831, the MIC of ciprofloxacin to FREC070701 was decreased from 64 to $1 \mu \mathrm{g} \mathrm{ml}^{-1}$, which reached sensitive margin values of ciprofloxacin to E. coli on the basis of the interpretive criteria recommended by the Clinical and Laboratory Standards Institute. At the same time, the MICs of levofloxacin to FREC070701 were also reduced at different degrees when treated with $3,10,30$ and $100 \mu \mathrm{g} \mathrm{ml}^{-1}$ encapsulated PS-ODN831 liposome. After treatment with $100 \mu \mathrm{g} \mathrm{ml}^{-1}$ liposome-encapsulated PS-ODN831, the MIC of levofloxacin to FREC070701 was decreased from 32 to $1 \mu \mathrm{g} \mathrm{ml}^{-1}$. The MIC values of ciprofloxacin and levofloxacin to FREC070701 in the presence of free anti-acrB PS-ODN831 were only decreased a little. However, the MIC values of ciprofloxacin and levofloxacin for liposome-encapsulated mismatched PS-ODN0701 $\left(100 \mu \mathrm{g} \mathrm{ml}^{-1}\right)$, free PEI $\left(5.5 \mu \mathrm{g} \mathrm{ml}^{-1}\right)$ and liposome-encapsulated PBS group remained unchanged (Table 1 ).

\section{Real-time quantified assays for acrB expression}

We next, determined whether the restoration of antibiotic susceptibility in FREC070701 was correlated with the downregulation of $a c r B$ by the addition of anti-acrB PS-ODN831. To ascertain whether anti-acrB PSODN831 inhibits expression of target gene, the encapsulated anti-acrB PS-ODN831 liposomes were added to FREC070701 and the expression of $a c r B$ mRNA of FREC070701 was detected using real-time PCR. 

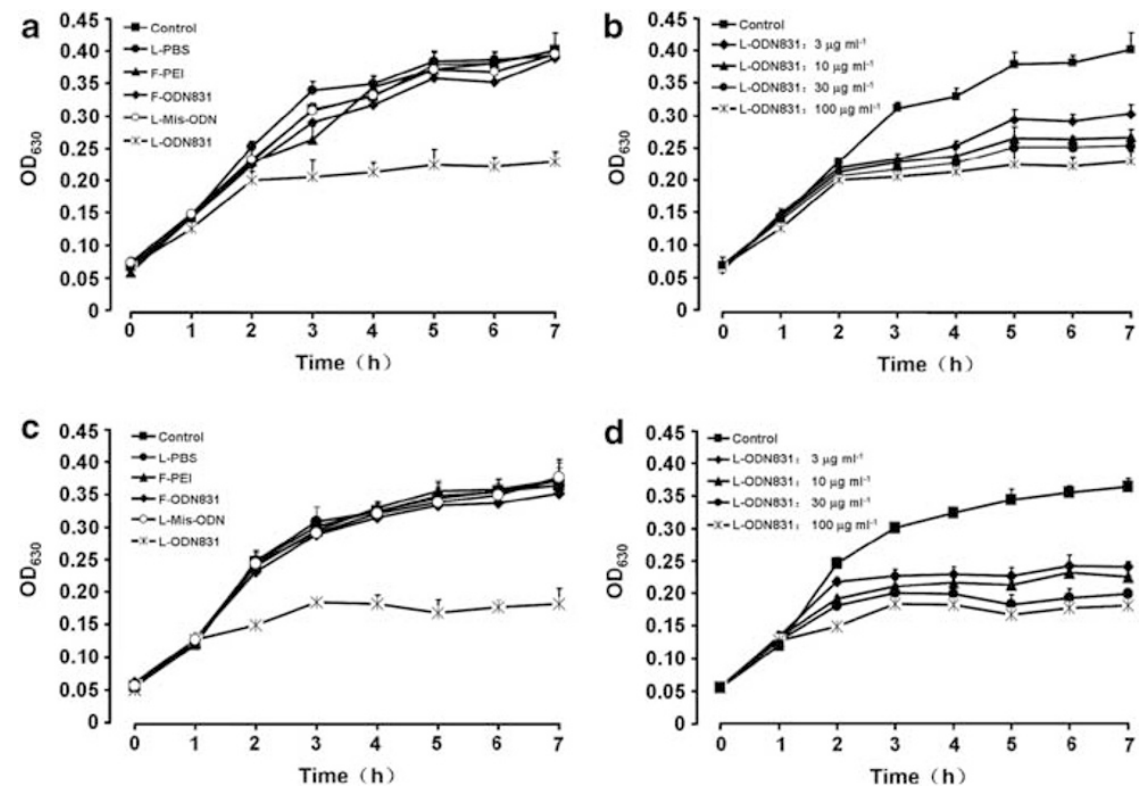

Figure 2 Effect of anti-acrB encapsulated PS-ODN831 on growth of the FREC070701 in liquid culture medium. The cells were cultured in liquid medium containing $6 \mu \mathrm{g} \mathrm{ml}^{-1}$ of ciprofloxacin (a and $\mathbf{b}$ ) or $12 \mu \mathrm{g} \mathrm{m} \mathrm{m}^{-1}$ of levofloxacin (c and $\mathbf{d}$ ). The data were shown as mean \pm s.d. of 10 samples.

Table 1 MICs of ciprofloxacin and levofloxacin for clinically isolated strain FREC070701 in the presence or absence of anti-acrB PS-ODN831

\begin{tabular}{lccc}
\hline & & \multicolumn{2}{c}{${\text { MICs }\left(\mu \mathrm{ml}^{-1}\right)}^{-1}$} \\
\cline { 3 - 4 } Groups & Concentrations of & Ciprofloxacin & Levofloxacin \\
\hline Control & 0 & 64 & 32 \\
L-PBS & 0 & 64 & 32 \\
L-Mis-ODN & 100 & 64 & 32 \\
F-PEI & 5.5 & 64 & 32 \\
F-ODN831 & 100 & 32 & 16 \\
L-ODN831 & 3 & 32 & 8 \\
L-ODN831 & 10 & 16 & 4 \\
L-ODN831 & 30 & 4 & 2 \\
L-ODN831 & 100 & 1 & 1
\end{tabular}

The MIC of ciprofloxacin to Escherichia coli: sensitive: $\mathrm{MIC} \leqslant 1 \mu \mathrm{gl}^{-1}$; resistant: $\mathrm{MIC} \geqslant 4 \mu \mathrm{g} \mathrm{ml}^{-1}$. The MIC of levofloxacin to $E$. coli: sensitive: MIC $\leqslant 2 \mu \mathrm{g} \mathrm{ml}^{-1}$; resistant: $\mathrm{MIC} \geqslant 8 \mu \mathrm{gml}^{-1}$.

Table 2 Oligonucleotide primers used for real-time PCR

\begin{tabular}{lllll}
\hline Gene & Primers & Primer sequence(5'-3') & $\begin{array}{c}\text { Location } \\
\text { (nucleotide) }\end{array}$ & Size(bp) \\
\hline \multirow{2}{*}{ AcrB } & Forward & 5'-TGGCGAGCAAACTGCCTAC-3' & $2540-2560$ & 126 \\
& Reverse & 5'-CCAGACACAGGAACACGACAA-3' & $2665-2685$ & \\
& & & & \\
16 6SrRNA & Forward & 5'-AGCGCAACCCTTATCCTTTGT-3' & $1095-1115$ & 85 \\
& Reverse & 5'-ATCCCCACCTTCCTCCAGTT-3' & $1179-1199$ & \\
\hline
\end{tabular}

Melting curve analysis is a simple, straightforward method to check qPCR reactions for primer-dimer artifacts and contamination, and to ensure reaction specificity and accurate quantification. Melting curve analysis demonstrated that each of the primer pairs, as described in Table 2, amplified a single predominant product with a distinct melting temperature. The melting temperature of $\operatorname{acrB}$ was $84^{\circ} \mathrm{C}$ and the melting temperature of $16 \operatorname{SrRNA}$ was $83^{\circ} \mathrm{C}$. This was confirmed by running $10 \mu \mathrm{l}$ of each product on an ethidium bromide-stained $1 \%$ agarose gel. The negative controls did not show any amplification product (data not shown).

To demonstrate that the PCR efficiencies for the target and the control gene were approximately equal, the values of the two standard curves were used to determine the absolute value of the slope of the $\log 5$ cDNA versus $\Delta \mathrm{Ct}$ (difference in the cycle threshold obtained for the two PCR systems with the same cDNA dilution) for the respective dilution. This validation experiment involved pairwise comparisons between $a c r B$ and 16SrRNA and the slope was 0.0023 (Figures 3a and b), demonstrating approximately equal PCR amplification efficiencies between $a c r B$ and $16 \operatorname{SrRNA}$.

Using the $2^{-\Delta \Delta \mathrm{Ct}}$ method, the change in gene expression of $\mathrm{acrB}$ mRNA in FREC070701 was normalized to 16SrRNA mRNA. Compared with the control group, the relative expression of $a c r B$ in antiacrB PS-ODN831-treated groups (3, 10, 30 and $100 \mu \mathrm{g} \mathrm{ml}^{-1}$ ) was decreased in a concentration-dependent manner to $67,36,17$ and $13 \%$ of control values, respectively. The relative expression of $a c r B$ in free PS-ODN831 group was $85 \%$ compared with the control group. Moreover, no detectable changes were observed in the liposomeencapsulated PBS, liposome-encapsulated mismatched PS-ODN and free PEI-treated groups (Figure 3c). This result demonstrates that the encapsulated PS-ODN831 not only enters the bacterial cells, but also interacts with the $a c r B$ mRNA.

\section{DISCUSSION}

The fluoroquinolone class of antimicrobial agents has been widely accepted in treating hospitalized and community patients for the treatment of infection caused by E. coli. With the increasing use of quinolones, there have been many reports on the increasing incidence of quinolone resistance in E. coli. ${ }^{2,5}$ The monitoring result of global SMART central indicated that the susceptibility rate of $E$. coli to 

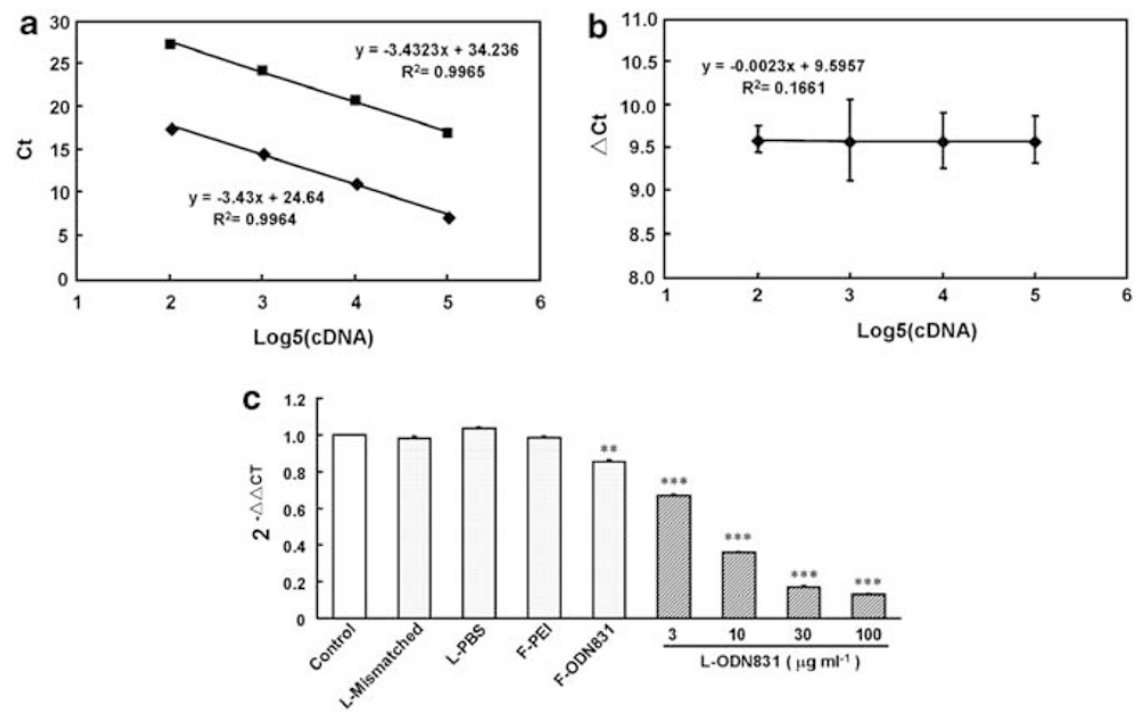

Figure 3 Relative mRNA expression of acrB of FREC070701 detected by real-time PCR. (a) Standard curves for acrB and 16SrRNA using cDNA from control. (b) Relative PCR efficiency of amplification for $a c r B$ and 16SrRNA using the respective primers. (c) Relative mRNA expression of acrB of FREC070701. $\Delta \Delta C_{\mathrm{t}}=\left(C_{\mathrm{t} \cdot \text { acrB }}-C_{\mathrm{t} \cdot 16 \mathrm{~s}}\right)_{\text {treatment }}-\left(C_{\mathrm{t} \cdot \mathrm{acrB}}-C_{\mathrm{t} \cdot 16 \mathrm{~S}}\right)_{\text {control. }}$ (mean $\left.\pm \mathrm{s} . \mathrm{d} ., \mathrm{n}=3\right)$. ${ }^{* *} P<0.05$ vs control and ${ }^{* * *} P<0.01$ vs control.

ciprofloxacin and levofloxacin compared with the other agents tested was the lowest in Asia-Pacific region including China in 2005. ${ }^{17}$

Antisense oligonucleotides are in theory designed to specifically modulate the transfer of the genetic information to protein. On the basis of mechanism of action of antisense, oligonucleotide can be discerned two classes: (a) the RNase H-dependent oligonucleotides, which induce the degradation of mRNA; and (b) the steric-blocker oligonucleotides, which physically prevent or inhibit the progression of splicing or the translational machinery. Oligonucleotide-assisted RNase H-dependent reduction of targeted RNA expression can be quite efficient, reaching $80-95 \%$ downregulation of protein and mRNA expression. Furthermore, in contrast to the steric-blocker oligonucleotides, RNase H-dependent oligonucleotides, such as phosphorothioate oligonucleotides, can inhibit protein expression when targeted to widely separated areas in the coding region. ${ }^{18-20}$

Mechanisms in fluoroquinolone resistance of E. coli fall into two principal categories: alterations in drug targets (for example DNA gyrase or topoisomerase IV) ${ }^{21-26}$ and decreased cellular accumulation of quinolones. The latter involves the major and constitutively expressed multi-drug efflux pump, AcrAB-TolC. ${ }^{27,28}$ The drug proton antiporter AcrB, which is located in the inner membrane, captures its substrates within the phospholipid bilaye ${ }^{29}$ and transports them into the external medium via the OM channel TolC. ${ }^{30}$ The cooperation of AcrB and TolC is mediated by the periplasmic protein AcrA, which has a large periplasmic domain..$^{31,32}$ As the three components are required for efficient transport of drugs, disruption of one of the three proteins by chemical compounds results in hypersusceptibility of E. coli to various antibiotics. ${ }^{33}$ Similarly, inhibition of AcrAB-TolC at RNA level is likely to be an effective approach to enhance the susceptibility of FREC.

Traditional antibiotics are increasingly suffering from the emergence of multidrug resistance among pathogenic bacteria. A range of novel approaches to control microbial infections is being investigated as potential alternative treatments. An antimicrobial alternative could be the combination of conventional antimicrobial antibiotics with efflux pump inhibitors, which block multidrug efflux systems. Efflux pump inhibitors could increase intracellular concentration of an antibiotic and restore its antibacterial activity of the antibiotic. ${ }^{34,35}$ A new potential approach to inhibit efflux pump is the use of synthetic antisense oligonucleotides, which are complementary and antisense relative to mRNA, leading to inhibition of gene product synthesis. The development of antisense oligonucleotides has shown some promise to reverse antibiotics resistance. ${ }^{36-38}$ Interrupting expression of resistance genes in this manner could restore susceptibility to key antibiotics, which would be co-administered with the antisense compound. This would extend the lifespan of existing antibiotics, which offer clinically proven therapies, and are often cheaper, more effective or less toxic than the alternatives. ${ }^{11}$

In our study, liposome-encapsulated anti-acrB PS-ODN831 reduced the expression of $a c r B$ gene of FREC070701 strain in a concentration-dependent manner. And when FREC070701 strain was treated with PS-ODN831, ciprofloxacin and levofloxacin could remarkably inhibit growth of FREC070701 strain. So we concluded that through inhibiting acrB mRNA expression, PS-ODN831 could decrease the expression of the AcrB protein and inhibit the drug efflux activity of $E$. coli strains. This method might provide a feasible strategy to recover antibiotic susceptibility in fluoroquinolone-resistant $E$. coli, and $a c r B$ mRNA may prove to be a promising drug target to combat FREC infections in the near future.

\section{METHODS}

\section{Chemicals}

Levofloxacin and ciprofloxacin were purchased from the National Institute for the Control of Pharmaceutical and Biological Products (Beijing, China). Polyethylenimine (PEI, $25 \mathrm{kDa}$ ) was purchased from Aldrich-Sigma (St Louis, MO, USA). Egg yolk phosphatidylcholine was obtained from Xi'an Libang Pharmaceutical Co., Ltd (Xi'an, China). $N$-(carbonyl-methoxypolyethyleneglycol-2000)-1,2-distearoyl-sn-glycero-3-phosphoethanolamine ( $\mathrm{PEG}_{2000}$-DSPE) was purchased from HeliCal Technology Ltd (Vancouver, BC, Canada). Dimyristoyl phosphatidylglycerol (DMPG) was purchased from Lipoid (Ludwigshafen, Germany). All culture media were purchased from Beijing Land Bridge Technology Co., Ltd (Beijing, China). All other chemicals and solvents were of analytical grade quality. 


\section{Organisms}

The E. coli clinical strain FREC070701, which was resistant to ciprofloxacin and levofloxacin used in this study, was obtained from patients in Xijing Hospital (Xi'an, China). The strain expressed $a c r B$, which is confirmed by PCR detection, and the mutation of DNA gyrase or topoisomerase IV was not detected (data not shown). We also used the laboratory strain E. coli ATCC25922 as the test organism and reference strain according to the quality control measures.

\section{Antisense oligonucleotides}

We designed a series of PS-ODNs targeting gene acrB of E. coli strain with RNAstructure 4.6 software (Mathews Lab, Rochester, NY, USA). The identification of the sensitive region of gene $a c r B$ and optimization of anti-acrB PSODNs for efficacious gene-specific antisense inhibition were verified by modified MIC assay of PS-ODNs (Supplementary Table S1). The sequence of the most active PS-ODN831 among these oligonucleotides in this study was: 5'GATGTCGTAGTTCTCACC-3' (PS-ODN831), which is complementary in sequence to nucleotide 814-831 in the coding region $a c r B$ mRNA in strain FREC070701. The control-mismatched sequence of this antisense PSODN0701, which was randomly aligned with the same number of bases, is 5'-CGAGTCCCTTTTTACCAA-3'. The PS-ODNs were synthesized by Aoke Biotechnology Limited-liability Company (Beijing, China) and were fully phosphorothioated.

\section{Preparation of anionic liposome encapsulated with nano-sized PS-ODN831/PEI complexes}

In order to increase encapsulation efficiencies of anionic liposome, PSODN831 and PEI were condensed into PS-ODN/PEI nanometer particle, and then this nanometer complexes were enveloped into liposome. Nanometer PS-ODN/PEI complexes and anionic liposome were prepared as described previously. ${ }^{39}$ The encapsulation efficiency was found to be up to $80 \%$.

\section{Bacterial growth assay}

The bacterial strain FREC070701 was cultured for $12 \mathrm{~h}\left(\mathrm{OD}_{630}=0.5 \sim 0.6\right)$ and then cells were diluted to a concentration of $0.5 \times 10^{8}$ c.f.u ml ${ }^{-1}$. The diluted bacterial broth was mixed with liposome-encapsulated PBS, liposome-encapsulated mismatched PS-ODN0701 $\left(100 \mu \mathrm{g} \mathrm{ml}^{-1}\right)$, free PEI $\left(5.5 \mu \mathrm{g} \mathrm{m}^{-1}\right)$, free PS-ODN831 $\left(100 \mu \mathrm{g} \mathrm{m}^{-1}\right)$ or liposome-encapsulated PS-ODN831 $(3,10,30$ or $100 \mu \mathrm{g} \mathrm{ml}^{-1}$ ). The mix cultures were incubated at $37^{\circ} \mathrm{C}$ with moderate agitation (210 r.p.m.) for 6 h. Then the cultures were diluted in a suitable gradient and $50 \mu \mathrm{l}$ of diluted cells were spread onto Mueller-Hinton agar which contained $6 \mu \mathrm{g} \mathrm{ml}^{-1}$ of ciprofloxacin or $12 \mu \mathrm{g} \mathrm{ml}^{-1}$ of levofloxacin. Plates were incubated for $48 \mathrm{~h}$ at $37^{\circ} \mathrm{C}$. The number of colonies was counted for plates with $>10$ and $<500$ colonies. The total colony-forming unit (CFU) per sample was determined by correcting the colony count from the dilution factor.

To determine the FREC070701 growth in the broth medium, $0.5 \times 10^{8}$ c.f.u ml ${ }^{-1}$ cell dilution was mixed with liposome-encapsulated PBS, liposome-encapsulated mismatched PS-ODN0701 $\left(100 \mu \mathrm{g} \mathrm{ml}^{-1}\right)$, free PEI $\left(5.5 \mu \mathrm{g} \mathrm{ml}^{-1}\right)$, free PS-ODN831 $\left(100 \mu \mathrm{g} \mathrm{ml}^{-1}\right)$ or liposome-encapsulated PSODN831 $\left(3,10,30\right.$ or $\left.100 \mu \mathrm{g} \mathrm{ml}^{-1}\right)$. In all, $100 \mu \mathrm{l}$ mixture containing $6 \mu \mathrm{g} \mathrm{ml}^{-1}$ of ciprofloxacin or $12 \mu \mathrm{g} \mathrm{ml}^{-1}$ of levofloxacin was added into a 96-well microtiter plate and the culture was incubated at $37^{\circ} \mathrm{C}$ with 210 r.p.m. agitation. The OD of each well was measured at different time points with a microplate reader (Bio-Rad laboratories, Tokyo, Japan) at $630 \mathrm{~nm}$.

\section{Bacterial susceptibility testing}

The MICs of ciprofloxacin and levofloxacin for FREC070701 were determined by a two-fold dilution tube method according to the guidelines of the Clinical and Laboratory Standards Institute. Quality control was assured by E. coli ATCC 25922 in every batch. Briefly, serial dilutions of antibiotics in Mueller-Hinton broth were prepared and the bacterial culture was mixed with liposome-encapsulated PBS, liposome-encapsulated mismatched PS-ODN0701 $\left(100 \mu \mathrm{g} \mathrm{ml}^{-1}\right)$, free PEI $\left(5.5 \mu \mathrm{g} \mathrm{ml}^{-1}\right)$, free PS-ODN831 $\left(100 \mu \mathrm{g} \mathrm{ml}^{-1}\right)$ or liposome-encapsulated PS-ODN831 $(3,10,30$ or $\left.100 \mu \mathrm{g} \mathrm{ml}^{-1}\right)$. The mixture $(50 \mu \mathrm{l})$ was then added to each tube to achieve a final inoculum of $5 \times 10^{5} \mathrm{cells}^{-1}$. Incubation was made at $37^{\circ} \mathrm{C}$ for $24 \mathrm{~h}$. After incubation, $100 \mu \mathrm{l}$ of $1 \%$ triphenyl tetrazolium chloride, a colorimetric indicator, was added into each tube and cells were further incubated for $3 \mathrm{~h}$ at $37^{\circ} \mathrm{C}$. The lowest concentration of antibiotics that resulted in complete inhibition of bacterial growth was indicated by the tetrazolium chloride-based MIC. Lack of bacterial growth showing no color change from the colorimetric indicator would demonstrate that antibiotics had an inhibitory effect.

\section{RNA isolation and reverse transcription}

The total RNA was extracted from the bacterial culture by using an RNAprep Tissue/Bacteria kit (Tiangen biotech Co.Ltd, Beijing, China) according to the manufacturer's instructions. The cDNA of $a c r B$ was synthesized by reverse transcription from $1 \mu \mathrm{g}$ of each RNA sample. The cDNA was stored at $-20^{\circ} \mathrm{C}$.

\section{Real time PCR reaction}

The resulting cDNA was amplified by real-time PCR (BIOER line-gene K, Bioer Technology Co., Ltd, Hangzhou, China) using the gene-specific oligonucleotide primers (Table 2). All primers were synthesized commercially (Takara biotechnology Co., Ltd, Dalian, China). The real time PCR was run using SYBR Green I (Takara biotechnology Co., Ltd). The PCR reagents consisted of $12.5 \mu \mathrm{l}$ of $2 \times$ SYBR Premix Ex Taq (Takara biotechnology Co., Ltd), $1 \mu \mathrm{l}$ of each primer $(5 \mu \mathrm{M})$ and $5 \mu \mathrm{l}$ of sample cDNA, in a final volume of $25 \mu \mathrm{l}$. Each plate included its own negative controls, where all the reaction reagents except for cDNA were used. The thermal cycling conditions were an initial denaturation step at $95^{\circ} \mathrm{C}$ for $2 \mathrm{~min}, 40 \mathrm{cycles}$ at $94^{\circ} \mathrm{C}$ for $30 \mathrm{~s}, 56^{\circ} \mathrm{C}$ for $20 \mathrm{~s}$ and $72^{\circ} \mathrm{C}$ for $30 \mathrm{~s}$. The melting curves of the PCR products were acquired by stepwise increase of the temperature from $70-94^{\circ} \mathrm{C}$.

\section{Comparative calculation and determination of relative expression} levels of $a c r B$ of different treated groups

Relative expression of $a c r B$ mRNA was calculated using the comparative $\Delta \Delta \mathrm{Ct}$ method. For the $\Delta \Delta \mathrm{Ct}$ calculation to be valid, the amplification efficiencies of the target gene and reference gene must be approximately equal. A valid method for assessing if two amplicons have the same efficiency was to look at how $\Delta \mathrm{Ct}$ varies with template dilution. The cDNA of control group was five-fold series diluted and the analysis was performed as follows: for each sample, a difference in the cycle threshold values $(\Delta \mathrm{Ct})$ was calculated for target gene $(a \mathrm{cr} B)$ by taking the mean Ct of duplicate tubes and subtracting the mean $\mathrm{Ct}$ of the duplicate tubes for reference gene (16SrRNA) measured on an aliquot from the same RT reaction. $\Delta \mathrm{Ct}=\mathrm{Ct}($ acrB $)-\mathrm{Ct}(16 \operatorname{SrRNA})$. A plot of the $\log 5 \mathrm{cDNA}$ dilution versus $\Delta \mathrm{Ct}$ was made. If the absolute value of the slope is close to zero, the efficiencies of the target gene and reference gene are similar, and the $\Delta \Delta \mathrm{Ct}$ calculation for the relative quantification of target may be used. The $\Delta \Delta \mathrm{Ct}$ values were calculated using the following equation: $\Delta \Delta \mathrm{Ct}=\Delta \mathrm{Ct}$ (treatment) $-\Delta \mathrm{Ct}$ (control). The $\Delta \mathrm{Ct}$ for the treated sample was then subtracted from the $\Delta \mathrm{Ct}$ for the untreated, control sample to obtain a $\Delta \Delta \mathrm{Ct}$. The mean of these $\Delta \Delta$ CT measurements was then used to calculate expression of acrB $\left(2^{-\Delta \Delta C t}\right)$ relative to $16 S r R N A$ and normalized to the untreated control as follows: Relative expression $=2^{-\Delta \Delta \mathrm{Ct}}$. Analyses of gene expression data using the $2^{-\Delta \Delta \mathrm{Ct}}$ method have been reported in the literatures. ${ }^{40,41}$ The evaluation of $2^{-\Delta \Delta \mathrm{Ct}}$ indicates the change in gene expression relative to the untreated control.

\section{Statistical analysis}

Values are expressed as mean \pm s.d. and one-way ANOVA analysis followed by the SNK $t$-test. A value of $\mathrm{P}<0.05$ is considered statistically significant.

\section{CONFLICT OF INTEREST}

The authors declare no conflict of interest.

\section{ACKNOWLEDGEMENTS}

This research was supported by grants from the National Natural Science Foundation of China (No. 30901813 and 30973666) and Natural Science Foundation of Shaanxi Province (No. 2009JQ4004). 
1 Smith, J. L., Fratamico, P. M. \& Gunther, N. W. Extraintestinal pathogenic Escherichia coli. Foodborne. Pathog. Dis. 4, 134-163 (2007).

2 Linder, J. A., Huang, E. S., Steinman, M. A., Gonzales, R. \& Stafford, R. S. Fluoroquinolone prescribing in the United States: 1995 to 2002. Am. J. Med. 118, 259-268 (2005).

3 Hooper, D. C. Emerging mechanisms of fluoroquinolone resistance. Emerg. Infect. Dis. 7, 337-341 (2001).

4 Bearden, D. T. \& Danziger, L. H. Mechanism of action of and resistance to quinolones. Pharmacotherapy 21 (10 Part 2), 224S-232S (2001).

5 Zervos, M. J. et al. Relationship between fluoroquinolone use and changes in susceptibility to fluoroquinolones of selected pathogens in 10 United States teaching hospitals, 1991-2000. Clin. Infect. Dis. 37, 1643-1648 (2003).

6 Kahlmeter, G., Menday, P. \& Cars, O. Non-hospital antimicrobial usage and resistance in community-acquired Escherichia coli urinary tract infection. J. Antimicrob. Chemother. 52, 1005-1010 (2003).

7 Wang, H., Dzink-Fox, J. L., Chen, M. \& Levy, S. B. Genetic characterization of highly fluoroquinolone-resistant clinical Escherichia coli strains from China: role of acrR mutations. Antimicrob. Agents. Chemother. 45, 1515-1521 (2001).

8 Kawai, S. et al. Susceptibility surveillance of clinical isolates to fluoroquinolone antimicrobial agents from 2003 to 2008: post-marketing study of prulifloxacin. Jpn. J. Antibiot. 63, 242-254 (2010).

9 Carlet, J., Ben Ali, A. \& Chalfine, A. Epidemiology and control of antibiotic resistance in the intensive care unit. Curr. Opin. Infect. Dis. 17, 309-316 (2004).

10 Muzzi, A., Masignani, V. \& Rappuoli, R. The pan-genome: towards a knowledge-based discovery of novel targets for vaccines and antibacterials. Drug. Discov. Today. 12, 429-439 (2007).

11 Geller, B. L. Antibacterial antisense. Curr. Opin. Mol. Ther. 7, 109-113 (2005).

$12 \mathrm{Hou}, \mathrm{Z}$. et al. Restoration of antibiotic susceptibility in methicillin-resistant Staphylococcus aureus by targeting mecR1 with a phosphorothioate deoxyribozyme. Clin. Exp. Pharmacol. Physiol. 34, 1160-1164 (2007)

$13 \mathrm{Hou}, \mathrm{Z}$. et al. Inhibition of beta-lactamase-mediated oxacillin resistance in Staphylococcus aureus by a deoxyribozyme. Acta. Pharmacol. Sin. 28, 1775-1782 (2007).

14 Meng, J. et al. Novel anion liposome-encapsulated antisense oligonucleotide restores susceptibility of methicillin-resistant Staphylococcus aureus and rescues mice from lethal sepsis by targeting mecA. Antimicrob. Agents. Chemother. 53, 2871-2878 (2009).

15 Meng, J. et al. Restoration of oxacillin susceptibility in methicillin-resistant Staphylococcus aureus by blocking the MecR1-mediated signaling pathway. J. Chemother. 18, 360-365 (2006).

16 Wang, $\mathrm{H}$. et al. oprM as a new target for reversion of multidrug resistance in Pseudomonas aeruginosa by antisense phosphorothioate oligodeoxynucleotides. FEMS. Immunol. Med. Microbiol. 60, 275-282 (2010).

17 Paterson, D. L. et al. In vitro susceptibilities of aerobic and facultative Gram-negative bacilli isolated from patients with intra-abdominal infections worldwide: the 2003 Study for Monitoring Antimicrobial Resistance Trends (SMART). J. Antimicrob. Chemother. 55, 965-973 (2005).

18 Larrouy, B. et al. RNase H-mediated inhibition of translation by antisense oligodeoxyribonucleotides: use of backbone modification to improve specificity. Gene 121, 189-194 (1992).

19 Dean, N. M., McKay, R., Condon, T. P. \& Bennett, C. F. Inhibition of protein kinase Calpha expression in human A549 cells by antisense oligonucleotides inhibits induction of intercellular adhesion molecule 1 (ICAM-1) mRNA by phorbol esters. J. Biol. Chem. 269, 16416-16424 (1994).

20 Dias, N. \& Stein, C. A. Antisense oligonucleotides: basic concepts and mechanisms. Mol. Cancer. Ther. 1, 347-355 (2002).

21 Chenia, H. Y., Pillay, B. \& Pillay, D. Analysis of the mechanisms of fluoroquinolone resistance in urinary tract pathogens. J. Antimicrob. Chemother. 58, 1274-1278 (2006).
22 Nakamura, S., Nakamura, M., Kojima, T. \& Yoshida, H. gyrA and gyrB mutations in quinolone-resistant strains of Escherichia coli. Antimicrob. Agents. Chemother. 33, 254-255 (1989).

23 Yoshida, H., Bogaki, M., Nakamura, M., Yamanaka, L. M. \& Nakamura, S. Quinolone resistance-determining region in the DNA gyrase gyrB gene of Escherichia coli. Antimicrob. Agents. Chemother. 35, 1647-1650 (1991).

24 Ruiz, J., Casellas, S., Jimenez de Anta, M. T. \& Vila, J. The region of the parE gene, homologous to the quinolone-resistant determining region of the gyrB gene, is not linked with the acquisition of quinolone resistance in Escherichia coli clinical isolates. J. Antimicrob. Chemother. 39, 839-840 (1997).

25 Vila, J., Ruiz, J., Goni, P. \& Jimenez de Anta, T. Quinolone-resistance mutations in the topoisomerase IV parC gene of Acinetobacter baumannii. J. Antimicrob. Chemother. 39, 757-762 (1997).

26 Jung, D. et al. Isolation of quinolone-resistant Escherichia coli found in major rivers in Korea. J. Microbiol. 44, 680-684 (2006).

27 Oethinger, M., Kern, W. V., Jellen-Ritter, A. S., McMurry, L. M. \& Levy, S. B. Ineffectiveness of topoisomerase mutations in mediating clinically significant fluoroquinolone resistance in Escherichia coli in the absence of the AcrAB efflux pump. Antimicrob. Agents. Chemother. 44, 10-13 (2000).

28 Hooper, D. C. Mechanisms of fluoroquinolone resistance. Drug. Resist. Updat. 2 , 38-55 (1999).

29 Zgurskaya, H. I. \& Nikaido, H. Bypassing the periplasm: reconstitution of the AcrAB multidrug efflux pump of Escherichia coli. Proc. Natl Acad. Sci. USA 96, 7190-7195 (1999).

30 Fralick, J. A. Evidence that TolC is required for functioning of the Mar/AcrAB efflux pump of Escherichia coli. J. Bacteriol. 178, 5803-5805 (1996).

31 Tikhonova, E. B., Wang, Q. \& Zgurskaya, H. I. Chimeric analysis of the multicomponent multidrug efflux transporters from gram-negative bacteria. J. Bacteriol. 184, 64996507 (2002).

32 Elkins, C. A. \& Nikaido, H. Substrate specificity of the RND-type multidrug efflux pumps $A c r B$ and $A c r D$ of Escherichia coli is determined predominantly by two large periplasmic loops. J. Bacteriol. 184, 6490-6498 (2002).

33 Okusu, H., Ma, D. \& Nikaido, H. AcrAB efflux pump plays a major role in the antibiotic resistance phenotype of Escherichia coli multiple-antibiotic-resistance (Mar) mutants. J. Bacteriol. 178, 306-308 (1996).

34 Fiamegos, Y. C. et al. Antimicrobial and efflux pump inhibitory activity of caffeoylquinic acids from Artemisia absinthium against gram-positive pathogenic bacteria. PLoS. One. 6, e18127 (2011)

35 Singh, M. et al. Effect of efflux pump inhibitors on drug susceptibility of ofloxacin resistant Mycobacterium tuberculosis isolates. Indian J. Med. Res. 133, 535-540 (2011).

36 White, D. G. et al. Inhibition of the multiple antibiotic resistance (mar) operon in Escherichia coli by antisense DNA analogs. Antimicrob. Agents. Chemother. 41, 2699-2704 (1997).

37 Torres Viera, C. et al. Restoration of vancomycin susceptibility in Enterococcus faecalis by antiresistance determinant gene transfer. Antimicrob. Agents. Chemother. 45, 973-975 (2001).

38 Sarno, R., Ha, H., Weinsetel, N. \& Tolmasky, M. E. Inhibition of aminoglycoside 6'-Nacetyltransferase type Ib-mediated amikacin resistance by antisense oligodeoxynucleotides. Antimicrob. Agents. Chemother. 47, 3296-3304 (2003).

39 Chen, T., Wang, Z., Wang, R., Lu, T. \& Wang, W. Polyethylenimine-DNA solid particles for gene delivery. J. Drug. Target. 15, 714-720 (2007).

40 Schmittgen, T. D. et al. Quantitative reverse transcription-polymerase chain reaction to study mRNA decay: comparison of endpoint and real-time methods. Anal. Biochem. 285, 194-204 (2000).

41 Winer, J., Jung, C. K., Shackel, I. \& Williams, P. M. Development and validation of real-time quantitative reverse transcriptase-polymerase chain reaction for monitoring gene expression in cardiac myocytes in vitro. Anal. Biochem. 270, 41-49 (1999).

Supplementary Information accompanies the paper on The Journal of Antibiotics website (http://www.nature.com/ja) 